\title{
The challenges of recovering from individual and cultural trauma in Toni Morrison's Home
}

\author{
AITOR IBARROLA* \\ Universidad de Deusto, Bilbao
}

Received: 24/07/2013. Accepted: 28/11/2013.

\begin{abstract}
The journey back home to Lotus, Georgia, that the protagonist of Morrison's latest novel, Frank Money, undertakes is planted with too many obstacles to turn it into the kind of "reconnecting experience" that would help him to recover from the traumas he suffers from. Frank's sense of alienation is exacerbated by some hateful childhood memories, his participation in the Korean War and his painful losses there, the failure to support the woman he loves, and the racism that he still experiences in the U.S. of the 1950s. Home (2012) offers ample grounds to discuss topics such as acts of remembrance, memory traces, the politics of mourning, and direct (and indirect) representations of trauma and sorrow. Yet, the main question the novel poses is to what extent Frank's journey to rescue his younger sister, Cee, helps him to achieve some kind of redemption and whether that redemption is fully materialized at the end of the novel.
\end{abstract}

KEYWORDS: Trauma Fiction, Toni Morrison, Home, Traumatic Memories, Politics of Mourning, Cultural Trauma, Recovery Processes, Representation of Trauma..

\section{RESUMEN}

El viaje de regreso a su hogar en Lotus, Georgia, que realiza el protagonista de la última novela de Morrison, Frank Money, está plagado de obstáculos que impiden convertirlo en esa "experiencia rehabilitadora" que le ayudaría a recuperarse de sus traumas. La alienación que Frank experimenta está ligada a recuerdos de infancia, a su participación en la Guerra de Corea, su incapacidad para satisfacer a la mujer que ama y las actitudes racistas todavía presentes en los EE.UU. de los años 50. Home (2012) ofrece un terreno fértil para abordar temas como el impacto de los recuerdos, la gestión de la memoria y el duelo o las formas de representar el dolor y los traumas en la ficción. Sin embargo, la cuestión clave en esta novela es hasta qué punto el viaje que Frank hace para rescatar a su hermana le ayuda a redimir aspectos de su pasado y si esa redención resulta finalmente completa.

PALABRAS CLAVE: Narrativa sobre trauma, Toni Morrison, Home, recuerdos traumáticos, gestión del duelo, el trauma cultural, procesos de recuperación, la representación del trauma.

*Address for correspondence: Aitor Ibarrola. Departamento de Lenguas Modernas y Estudios Vascos, Facultad de Ciencias Sociales y Humanas, Avenida de las Universidades, 24, 48007, Bilbao, Spain. Tel: 0034 968364365; Fax: 00 **; e-mail aitor.ibarrola@deusto.es. 
Trauma and recovery are complicated, layered processes for all individuals because both personal and cultural memory reactivate past experiences stored in bodily circuits.

Evelyn J. Schreiber, Race, Trauma, and Home in the Novels of Toni Morrison

Although the emphasis in these novels is on "working through", the novelists nevertheless remain attentive to the resistance and shock of trauma. The absence of the dead remains inviolable and forms the central silence around which the narratives circle but which they cannot finally redeem.

Anne Whitehead, Trauma Fiction

\section{INTRODUCTION}

Most critics and reviewers of Toni Morrison's latest novel, Home (2012), have agreed that it reprises many of the themes and narrative techniques that readers have become familiar with in her previous works of fiction. Although deceptively slight, Home brings together most of the resounding topics and storytelling devices that she mined in her earlier novels. According to Michiko Kakutani, "Home encapsulates all the themes that have fueled her fiction [...]: the hold that time past exerts over time present, the hazards of love (and its link to leaving and loss), the possibility of redemption and transcendence" (2012: np). Indeed, the novel can easily be read as an instance of "trauma fiction" in which the author is trying to rescue previously neglected historical periods and to give voice to generally repressed or forgotten stories from the perspective of the unprivileged (see Whitehead, 2004: 82). In order to do so, Morrison makes use of some of her staple narrative techniques such as the inclusion of multiple focalizers, the repetition of the same scenes from various viewpoints, intertextual references to earlier novels, and an intriguing dialogue going on between her main character and a kind of scribe -or implied author. All things considered, it may be said that Morrison manages to capture how many African Americans experienced the period of the $1950 \mathrm{~s}$, a period often idealized in the country's historical imagination, but which, as the novel shows, was not without its social complexities and blatant racial abuses (cf. Smith, 2012: 132).

Despite the presence of all those thematic strands and narrative devices reminiscent of her earlier novels, it would be incorrect to assume that Home is a work of fiction lacking in originality. To begin with, for a first time in her long writing career, Morrison has decided to focus primarily on a male protagonist, Frank "Smart" Money, and the difficulties he faces in forming an adequate manhood. Unlike her previous works -mostly covering female issues-, this book delves deep into typically masculine experiences such as the horrors of war, their injurious psychological effects, bonds of male friendship, and brotherly responsibilities (cf. Charles, 2012). The seminal work by Murphy (1994) and Connell (1995) regarding the social 
construction of hegemonic masculinities -in plural- and the urgent need to study their praxis should prove invaluable in tackling those topics in the novel. Although, as mentioned above, Morrison has often dealt with the unbearable weight of the past on the present, that weight is exponentially multiplied when the victim has been exposed to bigotry and injustice at home, and extreme violence and losses abroad. Churchwell notes that "Morrison returns to the 50s, an era she remembers, to mine the traumatic possibilities of the Korean War and of biological experiments on African-Americans" (2012: np). One last remarkable innovation in the novel is its narrative structure, which alternates the voices of the mentally unstable protagonist chapters in italics- and that of a more traditional -and apparently objective- scribe. The juxtaposition of these two voices does not only allow Morrison to investigate the complications of representing trauma in fiction, but it also invites her to consider and "negotiate the twin seductions of interiorization and exteriorization" (Christiansë, 2013: 5).

Home recounts the story of Frank Money, an African-American war veteran showing clear symptoms of PTSD, who has to return to his hometown in Georgia in order to save his younger sister Ycidra - or just Cee. One year after being discharged from the army, Frank is leading a disoriented and mostly empty existence in Seattle, tortured by horrifying flashbacks and gruesome hallucinations of his experiences in Korea. Then, he receives a letter from a friend of his sister's telling him to "Come fast. She be dead if you tarry" (Morrison, 2012: 8). His deeply-felt responsibility toward his sister, who is now his only family and has been " $a$ shadow for most of my life, a presence marking its own absence, or maybe mine" (103, italics in original), provides Frank with a new mission. However, Frank's journey across the country is far from being the kind of "reconnecting experience" that he needs to recover from the various traumas he suffers from. Cathy Caruth defines trauma as "the story of a wound that cries out, that addresses us in the attempt to tell us of a reality or truth that is not otherwise available" (1996: 4). In the case of Frank Money, it soon transpires that he has been the victim of some hateful childhood experiences, war shocks, and racial humiliations that he has long repressed and that produce that type of breach in his mind. As will become evident below, while it is undeniable that, on a personal level, Frank succeeds in rescuing his sister and quieting many of his own demons by the end of the journey, it is much more difficult to argue that the cultural and racial traumas that he bears are fully healed. As the two epigraphs to this article indicate, recovering from the profound damage caused by collective mental injuries is far more arduous, since, as Sam Durrant remarks, "racial memory threatens to destroy that [personal] sense of identity by dissolving the individual within a collective experience of negation" (2004: 80).

\section{MEMORY FRAGMENTS AND THE HAZARDS OF RE-MEMBERING}

Ron Eyerman and Evelyn Schreiber have argued that the traumas originating in slavery and the Middle Passage have constituted the kernel of collective memory and identity for most 
African Americans (2004: 60; 2010: 5). As these authors see it, even if most black Americans never experienced those calamitous circumstances and communal efforts to erase them have been made, a generational transmission of cultural trauma has occurred that has perpetuated their feeling of being rejected. Jeffrey Alexander notes that "Insofar as they identify the cause of trauma, and thereby assume such moral responsibility, members of collectivities define their solidarity relationships in ways that, in principle, allow them to share the sufferings of others" (2004: 1). In this regard, cultural trauma leaves indelible marks upon the group consciousness and causes a dramatic change in their identity, which is played out by future generations. A number of scholars have remarked that Toni Morrison's novels need to be studied as part of a tradition of postcolonial writing that is intent on figuring out how those memory images and enslaving discourses keep structuring their group's (unequal) relations and (disrupted) subjectivity (cf. Christiansë, 2013: 6-9; Peach, 1995: 13). Home is no exception to this general premise, for, in spite of the specificities of the historical period portrayed in the novel (McCarthyism) and the singularities of the main characters' experiences, there is no denying that many of the grievances suffered by their ancestors still resonate in their lives. Eyerman, following Halbwach's ideas, notes that "Individual identity is said to be negotiated within the collectively shared past. Thus, while there is always a unique, biographical memory to draw upon, it is described as being rooted in a collective history. Here collective memory provides the individual with a cognitive map within which to orient present behavior" (Eyerman, 2004: 65).

Perhaps the most evident sign that Home is a "trauma story" is the recurrent visits that the protagonist receives of ghosts from his past, which he has been trying to forget -mostly by drinking heavily-, but that insistently return to disturb his peace of mind. Caruth explains that "The historical power of trauma is not just that the experience is repeated after its forgetting, but that it is only in and through inherent forgetting that it is first experienced at all" (1996: 17). The broken memories that Frank Money has of his war experiences reveal this quality of not having been sufficiently grasped when they occurred and returning to haunt him now as if they were being experienced for a first time:

So, as was often the case when he was alone and sober, whatever the surroundings, he saw a boy pushing his entrails back in, holding them in his palms like a fortune-teller's globe shattering with bad news; or he heard a boy with only the bottom half of his face intact, the lips calling mama. And he was stepping over them, around them, to stay alive, to keep his own face from dissolving, his own colorful guts under that oh-so-thin sheet of flesh. Against the black and white of the winter landscape, blood red took center stage. They never went away, these pictures. (20)

No doubt, the fact that Frank lost his best two friends, Mike and Stuff, in Korea does not help him much in terms of being able to assimilate those terrifying memories. The reader soon realizes that the loss of his two "homeboys" is closely related to his incapacity to build connections with the surrounding world and to reorient his existence: "Sometimes, long after 
he'd been discharged, he would see Stuff's profile in a car stopped in traffic until the heart jump of sorrow announced his mistake. Abrupt, unregulated memories put a watery shine in his eyes. For months, only alcohol dispersed his best friends, the hovering dead he could no longer hear, talk to, or laugh with" (99). The harmful influence of these intrusive nightmares and hallucinations becomes most evident during the few months in which Frank enjoys a short respite while living with Lillian Florence Jones - or Lily-, who, by means of love and care, almost succeeds in "changing everything" and making him feel at home. At first, when Frank met her, he seemed determined to work through the pain of the loss: "Right then I decided to clean up. To hell with the dreams. I needed to make my homeboys proud. Be something other than a haunted, half-crazy drunk. So when I saw this woman at the cleaner's, I was wide open for her" (69, italics in original). Nevertheless, it soon becomes clear that those ghosts from his past will not be put to rest so easily, since he is pulled back into his indifference and self-absorption by them. According to Jacques Derrida, these ghosts usually have disjoining effects on identity and community since they refer to "certain others who are not present, nor presently living, either to us, in us, or outside us" (Derrida, 1994: xix). Whitehead has noted that the abundance of ghosts in much contemporary fiction is indicative of the need of many writers to explore "the nature of trauma as psychological possession" and to investigate the ways in which the past surfaces in the present (Whitehead, 2004: 6). In Home, Morrison is definitely taking seriously the need to consider all those traces of individual and collective traumatic memories to see how the resulting grieving processes may be resolved -or at least attenuated.

Several scholars have maintained that the ideas of home and community usually offer Morrison's characters a certain protection against racial trauma (Schreiber, 2010: 1; Smith, 2012: 131). However, in the case of Home, it would be much more difficult to support this view, since both Frank and Cee think of Lotus, Georgia, more as a "stifling place" from which one would like to escape than as one to return to: "Lotus, Georgia, is the worst place in the world, worse than a battlefield. At least on the field there is a goal, excitement, daring, and some chance of winning along with many chances of losing. [...] There was no goal other than breathing, nothing to win and, save for somebody else's quiet death, nothing to survive or worth surviving for" (83, italics in original). The novel opens with a short poem about a ghostly abode - certainly not a home- in which darkness and disorientation prevail: "Whose house is this? / Whose night keeps out the light / In here?" And the poem concludes by stressing the speaker's sense of estrangement and dissociation: "This house is strange. / Its shadows lie. / Say, tell me, why does its lock fit my key" (np). This short verse anticipates both Frank and Cee's sentiments toward a place where they could never feel at home. Frank's traumatic memories of the war and his sister's grave physical and psychic injuries resulting from the experiments in the hands of a white scientist often emerge as a continuation of the sense of alienation and emotional deprivation they endured as children in Lotus. Due to the cruelty that an extremely resentful step-grandmother inflicted and a couple of "primal scenes" 
of racial violence that left a profound scar on their psyche, both have difficulties in digesting the memories they keep from their childhood: "You never lived there so you don't know what it was like. Any kid who had a mind would lose it. [...] Only my sister in trouble could force me to even think about going in that direction" (84, italics in original). It is no wonder, then, that when Frank receives the note from her sister's friend to rush South in Cee's rescue, he should show great reluctance to do so, for almost anything is likely to bring back those discomfiting recollections: "Everything reminded him of something loaded with pain" (7-8). As Dominick LaCapra has argued, traumatic memories produce a dissociation between affect and representation, "one disorientingly feels what one cannot represent, one numbingly represents what one cannot feel" (LaCapra, 2001: 42), while the mourning process should in fact help to rearticulate the connection between affect and representation.

\section{HOME: A STORY OF MOURNING}

Of course, the literary motif of the journey back home is not new and, in principle, it would seem to be a convenient frame to allow the "hero" to re-member and rethink his relation to the surrounding reality. Frank Money's long journey from the West Coast to Georgia could well be seen as an opportunity to retrieve his painful memories and to provide them with a certain meaning that would heal some of his psychic wounds. But initiating this mourning process -which is closely related to the power of building a coherent narrative- is not an easy task because he has already been caught in a spiral of attempted amnesia and despondency that make recovery almost unthinkable: "He truly could not remember. [...] What he did remember was that as soon as Lily shut the door behind him, in spite of the seriousness of his mission, his anxiety became unmanageable. [...] Back was the free-floating rage, the selfloathing disguised as somebody else's fault. And all the memories that had ripened at Fort Lawton, from where, no sooner than discharged, he had begun to wander" (15). If anything becomes evident in the early stages of the novel it is that Frank is still trapped in the maze of a past that prevents him from looking into a future that would not merely repeat that past. As Caruth and LaCapra would put it, he seems unable to move beyond that mental condition in which he simply acts out the disorientation and violence that have taken possession of the best part of his self.

Perhaps the single glimpse of hope or potential point of departure for the mourning process is to be found in Frank's close relationship and strong sense of responsibility toward his sister. Cee has remained a reference and a standard to which all other women in his life are compared. Right after one of his disturbing visions -interestingly, one that questions his manhood-, Frank wonders whether his sister's illness and the call for help is not a sign: "Maybe his life had been preserved for Cee, which was only fair since she had been his original caring-for, a selflessness without gain or emotional profit. Even before she could walk he'd taken care of her" (34-35). As a few reviewers have noted, it is the selfless love 
that Frank professes for his sister that helps him to concentrate on his new mission and to begin to gain control over the memory images that had been haunting him (Charles 2012; Jones 2012). Although the loss of his two homeboys and his (unrecognized) murder of the scavenging Korean girl still weigh heavily on his conscience, midway through his journey Frank begins to reveal incipient signs of recovery: "Sitting on the train to Atlanta, Frank suddenly realized that those memories, powerful as they were, did not crush him anymore or throw him into paralyzing despair. He could recall every detail, every sorrow, without needing alcohol to steady him" (100). Judith Herman claims in Trauma and Recovery that only when trauma survivors manage to recall "in depth and in detail" their painful memories, and to refashion them into a meaningful narrative do they begin to show the capacity "to reconstruct and to integrate" those memories into their life stories (Herman, 1992: 175-84).

Apart from Frank's protective role toward his sister and his deep commitment to save her from the "arrogant, evil doctor" who had "sliced her up" (120), one other factor that also helps the protagonist to appease his demons and gain stability during the long journey is the assistance he receives from a number of good Samaritans that make it possible for him to get to his destination. Characters such as Reverend John Locke, Billy Watson, and several other African Americans do not only help Frank by providing the material means he needs to get to Georgia but, more importantly, they also give him advice and emotional support when he most needs it. Reverend Locke, for instance, warns him in the early stages of his odyssey about some of the obstacles he is likely to run into: "Listen here, you from Georgia and you been in a desegregated army and maybe you think up North is way different from down South. Don't believe it and don't count on it. Custom is just as real as law and can be just as dangerous" (19). Peach (1995) and other critics have given great importance to the role played by community and its sense of moral responsibility toward each member in Morrison's fiction. Frank Money's return journey to Lotus would have been fairly impossible without the sustenance and solidarity of these characters affording him, not just the money, food, and clothes he lacks, but also the empathy that, as most trauma scholars agree, is one of the sine qua nons to initiate a proper mourning process. "As the group shares mourning", notes Herman, "it simultaneously fosters hope for new relationships. Groups lend a kind of formality and ritual solemnity to individual grief; they help the survivor at once to pay homage to her losses in the past and to repopulate her life in the present" (Herman, 1992: 228).

In spite of the aforementioned elements favoring the process of working through the traumatic memories and providing new meaning for them, there are also other forces at work in the novel that seem to threaten that process. Besides his childhood and war traumas, Frank is reminded at various points that there are more profound, collective wounds that need to be healed by his people before a complete recovery is possible. Again, it is the pastor Reverend Locke who first makes clear to Frank that the fact that they have been fighting for their country has not substantially changed the situation of black Americans: "Well, you not the 
first by a long shot. An integrated army is integrated misery. You all go fight, come back, they treat you like dogs. Change that. They treat dogs better" (18). This crude statement proves correct a bit later when Frank comes across a black couple on a train who have been brutally beaten just for buying some coffee from a white establishment. The case of Thomas, Billy Watson's eleven-year-old son, who lost the use of his right arm because a rookie policeman shot him while he was playing on the sidewalk, is even sadder. When Frank shows his incredulity, Billy tells him that in Chicago "Cops shoot anything they want. This here's a mob city" (31). A few pages later, the protagonist himself experiences the bitter taste of racial humiliation when he and three other African-Americans are subjected by some officers to a random stop-and-frisk outside a shoe store. Leah Cohen remarks that "Threaded through the story are reminders of our country's vicious inhospitality toward some of its own" (2012: np). These racial incidents, as Durrant explains, act as reminders of a haunting prehistory of black citizens in the U.S: "The traumatic memory of slavery and the Middle Passage opens up something resembling an internal differend within Morrison's work, one that marks the gap between the subjective act of narration and the traumatic experience of racial oppression in which one is the object rather than the subject in one's history" (2004: 19, italics in original). Home oscillates between the protagonist's attempts at assimilating those traumatic episodes from his own past into his individual consciousness and the more difficult task of healing the wound of African American history -which has been invariably dominated by racism.

\section{THE TRIALS OF REPRESENTING TRAUMA IN NARRATIVE}

Combining these two movements in the novel -one of progress toward home and the inner self, and another of resistance, preventing the main character from coming to the real source of his problem- is by no means an easy task. As Whitehead notes, "[n]ovelists have frequently found that the impact of trauma can only be adequately represented by mimicking its forms and symptoms, so that temporality and chronology collapse, and narratives are characterized by repetition and indirection" (Whitehead, 2004: 3). The structure of Home may be said to follow the discontinuous and unpredictable patterns of narratives in which the past is never completely past and in which characters struggle to remember so as to have their lives properly pieced together. In a well-known review of Morrison's earlier novel, A Mercy, novelist John Updike complained that she "has a habit, perhaps traceable to the pernicious influence of William Faulkner, of plunging into the narrative before the reader has a clue to what is going on" (Updike, 2008: 112). Certainly, the reader of Home will also feel bewildered at different points of the novel because the presence of multiple focalizers and two distinct narrating voices has this effect of forcing the reader to seek new modes of referentiality, usually more indirect and associative. However, these unconventional formal devices, typical of trauma fiction, are very much consubstantial with the questions and challenges that extreme experiences of psychic pain pose such as the possibility of coming to 
final truths or the desirability of fully identifying with the victims' sufferings. Michael Rothberg has referred to these innovative techniques, which try to make us experience the unassimilated and "unspeakable" in human experience, as "traumatic realism". According to Rothberg, "[b]y focusing attention on the intersection between the ordinary and the extreme in the experience and writing of Holocaust survivors, traumatic realism provides an aesthetic and cognitive solution to the conflicting demands inherent in representing and understanding genocide" (Rothberg, 2000: 9). Very much the same thing could be stated about Morrison's efforts to capture in her fiction both the ordinary existence of her people and, also, the insurmountable political, economic, and socio-cultural limits and boundaries that they invariably face in U.S. society (Peach, 1995: 139).

Ron Charles has observed that one of the most intriguing and original structural devices in Home is the constant fluctuation between Frank's "raw, first-person voice", describing his trying experiences and an unnamed scribe's "sharp and unadorned" rendition of the same events (2012: $\mathrm{np}$ ). The presence of this scribe may confuse the reader, at first, because the main character repeatedly refers to the scribe's limited capacity to properly record his painful experiences. For instance, when Frank tells his interlocutor about his family's eviction from Texas when he was just a child, he taunts her: "You don't know what heat is until you cross the border from Texas to Louisiana in the summer. You can't come up with words that can catch it. / Trees give up. Turtles cook in their shells. Describe that if you know how" (41, italics in original). Despite these tensions, Herman (1992) has insisted on the key role played by an empathic listener who helps the trauma victim to control and put together his memories. The presence of somebody willing to bear witness and to assist in the recovery of those memories is crucial for the victim's reconstruction of a sense of self. But the witness/scribe must show the kind of empathy necessary to become a "true sharer" of the traumatic memories. As Laub explains, "[t]he listener has to feel the victim's victories, defeats and silences, know them from within, so that they can assume the form of testimony" (Laub, 1992: 58). Frank may have good reasons to suspect that his listener will not be able to accurately render his traumatic experiences in words: "You can't imagine it because you weren't there. You can't describe the bleak landscape because you never saw it. First let me tell you about cold. I mean cold. Korea cold hurts, clings like a kind of glue you can't peel off" (93); but the protagonist may also underestimate the scribe's powers to find a language more adequate to transcribe his psychic wounds. Kakutani is convinced that Morrison has found in this original figure a convenient reporter of the characters' experiences, with "a new, angular voice and straight-ahead storytelling that showcase her knowledge of her characters" (Kakutani, 2012: np). In the end, it could be argued that Home is a joint enterprise in which trauma victims, who offer their testimony, and a scribe, "who is, so to speak, the blank screen on which the event comes to be inscribed for the first time" (Laub, 1992: 57) cooperate to give shape and meaning to stories that had remained previously silent. The novel proves particularly successful precisely because victim/survivor and witness/scribe constantly check 
on each other's referential frameworks and their possible limitations, thus encouraging the reader to make the effort to integrate these complementary stories.

Apart from the dialogical structure and multi-perspectival focalization, which adds to the novel's complexity in the recovery of the characters' traumatic pasts, the presence of a figurative use of the language and the recurrent appearance of a number of ghostly figures also enrich our understanding of the characters' mental condition. Peach and Rushdy (1995, 1990) argue that the linguistic seams that Morrison exploits in her novels are related to the unspoken secrets and yearnings that her characters find so hard to articulate. Indeed, memory images such as the "black foot with its creamy pink and mud-streaked sole" (4) of the man secretly buried on the stud farm or the sneaking "child's hand sticking out and patting the ground" (94) in search of garbage in Korea insistently return to Frank Money's mind to remind him of those episodes he has repressed for too long. In Whitehead's (2004: 86) view, "Repetition mimics the effects of trauma, for it suggests the insistent return of the event and the disruption of narrative chronology and progression." In other cases, however, Morrison's metaphoric mode of expression may covertly foreshadow or anticipate significant incidents in the characters' lives. For instance, just before Cee begins to be experimented on by the white doctor, her friend explains to her that female melons are always sweeter than the male: "Sarah slid a long, sharp knife from the drawer and, with intense anticipation, of the pleasure to come, cut the girl in two" (66). Likewise, when Frank asks Billy Watson's handicapped, bright son what he wants to be when he grows up, "Thomas turned the knob with his left hand and opened the door. 'A man,' he said and left" (33), thus foreshadowing the closing scene of the novel in which Frank and his sister will be re-burying the black man from the stud farm and planting a wooden marker on the grave that reads: "Here Stands A Man" (145).

But probably the most mysterious presences -or absences- in the novel are two ghostly figures related, respectively, to Frank's personal war traumas and Cee's horrors in the hands of the scientist -and more broadly to a collective pathology which they seem unable to name. On one hand, there is the man in the pale blue zoot suit who visits Frank on a couple of occasions to remind him, I assume, of his tenuous grip on his sense of manhood: "He had heard about those suits, but never saw anybody wearing one. If they were the signals of manhood, he would have preferred a loincloth and some white paint artfully smeared on forehead and cheeks" (34). It is curious, though, that the last apparition of the zoot-suited man near the end of the novel takes place when the siblings are reburying the black man, and this time it is only Cee who sees him. On the other hand, when Cee is informed after her recovery that she will not be able to bear children, initially she seems to accept the fact as fair punishment for her gullibility. However, a few days later, she confesses to her brother that she cannot help thinking of that unborn baby as an aftermath of a deeper psycho-wound that transcends her own mistakes: “'Don't,' she said, pushing his hand away. 'I didn't feel anything at first when Miss Ethel told me, but now I think about it all the time. It's like there's a baby girl down here waiting to be born to. And now she has to find another 
mother'" (131). The intertextual reference to Sethe in Beloved, another mother haunted by her dead baby daughter, is inevitable here, and it also points at a cultural trauma deeplyrooted in slavery days. As Whitehead has noted, "[t]hrough intertextual reference to her own fiction, Morrison reveals that the trauma of slavery has not been laid to rest but resurfaces in the lives and actions of the protagonists" (Whitehead, 2004: 85).

\section{EVIDENT SIGNS OF RECOVERY}

In spite of evident hints in Home suggesting that, besides their individual wounds, the main characters suffer from a more serious form of cultural trauma, it would be difficult to argue that no degree of working through is accomplished in the novel. As a matter of fact, several reviewers have affirmed that the novel "brims with affection and optimism. The gains here are hard won, but honestly earned, and sweet as love" (Jones, 2012: np). It could be argued, indeed, that Frank and Cee's partial recovery at the end of the novel is especially remarkable because of the intense pain and isolation that we have seen them experiencing throughout the narrative. Elaine Scarry (1985) has described in great detail how physical and psychological pain come to deconstruct the victims' world, dislocating the self, and making it extremely difficult for them to grasp and communicate the roots of their problems. Frank and Cee would definitely be cases in point, since both their childhood memories and their brutal experiences away from home have left profound scars on their psyches. Morrison's novel, however, offers a number of clues about "the ways in which love and duty can redeem a blighted past" (Kakutani, 2012: np). But besides the love and duty that the main characters of the novel undoubtedly profess for each other, there is also the need to turn their memories into a narrative from which they themselves and others may gain valuable knowledge (Meyer, 2012).

Before they return to Lotus to have Cee healed by the local community of wise women, both siblings have been gravely damaged and adrift for some time. Ycidra had fallen victim of a pretentious young man who claimed to love her and married her, only to abandon her soon afterward, leaving her utterly defenseless in Atlanta. Because she was used to being protected by Frank, now on her own and with a deficient education, she is an easy prey for a wicked doctor who uses her as a guinea pig in his eugenics-based experiments. By the time her brother comes to rescue her, she is near death and her physical integrity will never be restored. Nonetheless, after a few months in the care of Ethel Fordham and the other women with the "seen-it-all-eyes" in Lotus, Cee is turned into a radically different person: "Cee was different. Two months surrounded by country women who loved mean had changed her. The women handled sickness as though it were an affront, an illegal, invading braggart who needed whipping" (121). Not only does Cee manage to make it through her serious physical illness but, more remarkably, she becomes an independent and strong woman who "would 
never again need rescue" (129). Both she and Frank realize that his excessive care in her youth had probably done little favor to her, and now she is ready to confront the future on her own, aware of her limitations: "[...] her brother was there with her, which was very comforting, but she didn't need him as she had before. He had literally saved her life, but she neither missed nor wanted his fingers at the nape of her neck telling her not to cry, that everything would be all right" (131). By the end of the novel, Cee is presented as having acquired a "newly steady self, confident, cheerful and occupied" (135), and the fact that she spends most of her time piecing together quilts may also be a convenient symbol indicating that she is also succeeding in finally putting together all those fragments of her life.

As mentioned earlier on, Frank begins to give signs of his slow recovery process even before he arrives in Lotus: "This feeling of safety and goodwill, he knew, was exaggerated, but savoring it was real. He convinced himself that somewhere nearby pork ribs sizzled on a yard grill and inside the house there was a potato salad and coleslaw and early sweet pees too" (118). Despite his earlier reluctance to return to the South, as Frank gets closer to the region he realizes that there are certain things there -the weather, the food, the pace of lifethat he immediately identifies with. So once he has fulfilled his main mission of saving his sister, he knows he is now ready to battle against his own "ghosts" in this more welcoming context: "Waving occasionally at passing neighbors or those doing chores on their porches, he could not believe how much he had once hated this place. Now it seemed both fresh and ancient, safe and demanding. [...] Frank tried to sort out what else was troubling him and what to do about it" (132). After witnessing his sister's physical and spiritual recovery, Frank realizes that it is time to confront his own traumas: one dating as far back as his childhood days in Lotus, when they saw the secret burial of a black man; the other related to the murder of the scavenging girl -who looked like Cee- that he himself committed in Korea after she sexually propositioned him. Frank had repressed the memories of these incidents by using some screen memories connected with those "primal scenes" of trauma: the beautiful horses on the farm, in one case, and the loss of his two homeboys and the fact that "the guard" (100) had been the one who brutally killed the girl, in the other. But now, as he tells the scribe, he seems ready to face the truth of those past events and to recover his deeply-hurt black male identity: "I have to say something to you right now. I have to tell the whole truth. I lied to you and lied to me. I hid it from you because I hid it from me. I felt so proud grieving over my dead friends" (133, italics in original). Frank demonstrates that he has come full circle by first admitting that "he had covered his guilt and shame with big-time mourning for his dead buddies" (135), which had allowed him to keep his murder of the Korean child hidden: "Now the hook was deep inside his chest and nothing would dislodge it. The best he could hope for was time to work it loose" (135). Soon after, Frank convinces his sister to go back with him to the stud farm where they had originally witnessed the burial. They dig up the body of the black man -itself a symbol for uncovering memories- and wrap it in the first quilt that Cee had made. With this unearthing and reburial of that "ghost" from their past, Frank and Cee 
finally come to face their childhood trauma, and the reader feels that they are now progressing toward maturity and responsibility.

Even nature seems to respond exultantly to the main characters' decision to rebury the man under the split-down-the-middle sweet bay tree and under the wooden marker that Frank had prepared for the occasion: "Wishful thinking, perhaps, but he could have sworn the sweet bay was pleased to agree [with the legend on the marker]. Its olive-green leaves went wild in the glow of a fat cherry-red sun" (145). This celebratory sunset clearly contrasts against the colorless memories that we have seen emerging in Frank's mind throughout most of the text. The book closes with a short poem which, again, makes evident the profound transformation that the two main characters have undergone and that, at least momentarily, they have found a place where they can belong together. In a similar line, Valerie Smith has concluded that "[b]y reclaiming their personal secrets, they are able to reclaim Lotus as their literal, physical home. Through their willingness to confront their past, they find their true home within them in the memories they share" (Smith, 2012: 135).

\section{CONCLUSION: CAN GHOSTS BE COMPLETELY EXORCISED?}

It is undeniable that Home ends on a very positive and optimistic note, since the main characters have journeyed deep within themselves to come to an understanding and a partial assimilation of the memories that had previously haunted them. In this sense, it could be argued that the concept of home in the novel is not so much related to a particular place but, rather, to that psychic space where the memory of the self dwells. Schreiber notes that, for Morrison, home is primarily "a space of security and comfort lodged in memory", usually "embedded in the unconscious" (Schreiber, 2010: 160). It has also been observed, though, that at least in the case of Frank Money, the existence of a physical location in which people recognize elements connected with their collective identity may also be of some assistance in their recovery process. Herrero and Baelo-Allué (2011: xi) have warned us about the tendency in trauma criticism to focus on the "individual/psychological perspective" at the expense of "historical and social contexts" which, as they argue, acquire great relevance in the case of postcolonial narratives. It would be difficult to understand the tortuous road that Frank and Cee have had to travel in the novel if one did not take into account the kind of prejudice and injustices that they suffered as children in Lotus, first, and in exile, later. As a few reviewers of the novel pointed out, these characters are representative of a new generation, coming of age in the 1950s, who were aware of the traumatic past of most African Americans and will carry on the Civil Rights Movement in the 1960s. Within the scope of the novel, however, it is difficult to speak of a mourning process that would transcend the very immediate reconstruction of the main characters' individual pasts or of a recovery that would involve a consideration of the broader cultural traumas. In this regard, 
Charles notes that "Home is a daringly hopeful story about the possibility of healing", but perhaps even more precisely about the possibility "of surviving in a shadow of peace" (Charles, 2012: np).

It would not be like Morrison, nor like trauma fiction, to let the reader assume that once Frank and Cee Money get over their particular regrets and mental blocks, they would be fully reintegrated and totally free to pursue their new ideals, regardless of the context. On the one hand, as Herman and others have underlined, "Resolution of trauma is never final; recovery is never complete. The impact of the traumatic event continues to reverberate throughout the survivor's lifecycle" (Herman, 1992: 211). This fact is abundantly illustrated in Home because every time Frank and Cee run across difficulties in their adventures away from home, some ghosts from their childhood are likely to be reawakened. The years of McCarthyism were still very problematical for African Americans, since signs of exclusion and segregation were plentiful in U.S. society. As Eyerman (2004: 80) sees it, "[f]or blacks this rejection after the raised hopes engendered by emancipation and reconstruction forced a rethinking of their relation to American society." On the other hand, the open-ended character of the novel is also suitable because, as Christiansë has claimed, a fundamental characteristic of Morrison's writing is that "mourning dominates, in an art of incompletion that seeks to register, if not accommodate, the realities of trauma" (Christiansë, 2013: 22). Indeed, her ethical poetics is based on the combination -and distinction- between an art that primarily remembers and, therefore, is all about recuperation, restoration, and recovery, and another one that "refuses to close the wound of African American history in recognition of the impossibility of ever fully coming to terms with the history of racism, the impossibility of abreacting an 'event' that did not take place at a singular, historically specific moment in time" (Durrant, 2004: 83). In short, then, it could be argued that while Home suggests that individual recovery from past traumatic experiences is usually possible, it is not so easy to bring the insidious effects resulting from cultural and collective negation to a closure.

\section{ACKNOWLEDGEMENTS}

The research carried out for the writing of this article has been partly funded by the Spanish Ministry of Economy and Competitiveness (codes: FFI 2011-23598 and CSO2011-24804). A shorter version of the article was presented at the Conference "Acts of Remembrance in Contemporary Narratives in English: Opening the Past for the Future", held at the University of Zaragoza in April 2013. My sincerest gratitude to Maite Escudero, Katrina Harack, David Lloyd, Marita Nadal and Constanza Río for their useful comments on the earlier version of the work I delivered in Zaragoza. Thanks also to Larry Muies for his revision of the final manuscript.

\section{REFERENCES}

Alexander, J. C. (2004). Toward a theory of cultural trauma. In J. C. Alexander, R. Eyerman, B. Giesen, N. L. Smelser \& P. Sztompka (Eds.), Cultural Trauma and Collective Identity (pp. 130). Berkeley, L. A. \& London: University of California Press. 
Caruth, C. (1996). Unclaimed experience : Trauma, narrative, and history. Baltimore \& London: The Johns Hopkins University Press.

Charles, R. (2012). Toni Morrison's Home, a restrained but powerful novel. Review of Home. The Washington Post. 1 May 2012. Retrieved from http://www.washingtonpost.com/entertainment/ books/book-review-toni-morrisons-home-a-estrained-but-powerful-novel/2012/04/30/gIQAKi WSsT story.html

Christiansë, Y. (2013). Toni Morrison: An ethical poetics. New York: Fordham University Press.

Churchwell, S. (2012). Does Toni Morrison's latest novel stand up to her best? Review of Home. The Guardian. 27 April 2012. Retrieved from http://www.guardian.co.uk/books/2012/apr/27/ tonimorrison-sarah-churchwell-home

Cohen, L. H. (2012). Point of return: Home, a novel by Toni Morrison. Review of Home. The New York Times. 17 May 2012. Retrieved from http://www.nytimes.com/2012/05/20/books/review/ home-a-novel-by-toni-morrison.html?pagewanted $=$ all\&_ $\mathrm{r}=0$

Connell, R. W. (1995). Masculinities. Berkeley \& L.A.: University of California Press.

Derrida, J. (1994). Exordium. In J. Derrida, The state of the debt, the work of mourning and the new international (P. Kamuf, Trans.) (pp. xvi-xx). New York \& London: Routledge (Original work in French published 1993).

Durrant, S. (2004). Postcolonial narrative and the work of mourning: J.M. Coetzee, Wilson Harris and Toni Morrison. Albany, New York: State University of New York Press.

Eyerman, R. (2004). Cultural trauma: Slavery and the formation of African American identity. In J. C. Alexander, R. Eyerman, B. Giesen, N. L. Smelser \& P. Sztompka (Eds.), Cultural trauma and collective identity (pp. 60-111). Berkeley, L. A. \& London: University of California Press.

Herman, J. L. (1992). Trauma and recovery: The aftermath of violence-from domestic abuse to political terror. New York: Basic Books.

Herrero, D. \& Baelo-Allué, S. (Eds.) (2011). Introduction. In The splintered glass: Facets of trauma in the post-colony and beyond (pp. ix-xxvi). Amsterdam \& New York: Rodopi.

Jones, T. (2012). Home by Toni Morrison: Review. Review of Home. San Francisco Gate. 6 May 2012. Retrieved from http://www.sfgate.com/books/article/Home-by-Toni-Morrison-review3536032.php

Kakutani, M. (2012). Soldier is defeated by war abroad, then welcomed back by racism. Review of Home. The New York Times. 7 May 2012. Retrieved from http://www.nytimes.com/2012/05/ 08/books/home-a-novel-by-toni-morrison.html?pagewanted $=$ all \& $\mathrm{r}=0$

LaCapra, D. (2001). Writing history, writing trauma. Baltimore \& London: The Johns Hopkins University Press.

Laub, D. (1992). Bearing witness or the vicissitudes of listening. In S. Felman \& D. Laub (Eds.), Testimony: Crises of witnessing in literature, psychoanalysis, and history (pp. 57-76). New York \& London: Routledge.

Meyer, L. (2012). Testimony and transformation: An exploration of the intersection of the arts of Toni Morrison and the potential therapeutic uses of narrative. In C. R. Gillespie (Ed.), Toni Morrison: Forty years in the clearing (pp. 237-244). Lanham, MD: Bucknell University Press.

Morrison, T. (2012). Home. New York: Knopf.

Murphy, P. F. (1994). Fictions of masculinity: Crossing cultures, crossing sexualities. New York \& London: New York University Press.

Peach, L. (1995). Toni Morrison. Modern Novelists Series. New York: St. Martin's Press.

Rothberg, M. (2000). Traumatic realism: The demands of holocaust representation. Minneapolis \& London: University of Minnesota Press.

Rushdy, A. H. A. (1990) 'Rememory': Primal scenes and constructions in Toni Morrison's novels. Contemporary Literature, 31(3), 300-323.

Scarry, E. (1985). Introduction. In The body in pain: The making and unmaking of the world (pp. 323). Oxford \& New York: Oxford University Press.

Schreiber, E. J. (2010). Race, trauma, and home in the novels of Toni Morrison. Baton Rouge, LA: Louisiana State University Press.

Smith, V. (2012). Epilogue: Home. In Toni Morrison: Writing the moral imagination (pp. 131-136). Malden, MA: Blackwell Publishing. 
Updike, J. (2008). Dreamy wilderness: Unmastered women in colonial Virginia. Review of $A$ Mercy. The New Yorker 38(35), 112-13. 3 November 2008. Retrieved from http://www.newyorker.com/arts/critics/books/2008/11/03/081103crbo_books_updike

Whitehead, A. (2004). Trauma fiction. Edinburgh: Edinburgh University Press. 